\title{
A Late Medieval Demonic Invasion of the Heavens
}

The starting point of this chapter is a particular moment in medieval intellectual history: the adaptation of the Aristotelian cosmological model by late medieval Christian thinkers, and its implications for thinking about demons. I will suggest that an increased feeling of human helplessness in the face of the cosmological pressures outlined in the Aristotelian model led some writers to suggest that demons worked with celestial influences to cause evil and suffering. My focus on this topic is part of a wider attempt to recover some of the numerous cosmologies, both written and unwritten, that are likely to have been conceived during the Middle Ages - since most, perhaps all, people have views of some sort about the structure and operations of the universe. ${ }^{1} \mathrm{My}$ discussion is also intended to contribute to ongoing historiographical debates about the fifteenth century coalescence of witchcraft mythologies, and the textual strategies that led to some types of ritual magic having a positive reception at the end of the Middle Ages.

As the Aristotelian model began to dominate medieval cosmological thought and to be adapted to essential theological principles, the physical location of demons seemed relatively unproblematic. At the centre of this cosmological model was Earth, enclosed first within the spheres of the four elements; then the spheres of the seven planets, a crystalline sphere and the empyrean heaven. ${ }^{2}$ The transparent celestial spheres, closely nested within one another like the layers of an onion (a popular analogy of the time) moved with continuous circular motions and exerted a powerful influence on the physical world. In the outermost sphere was the most sacred part of this cosmos, the empyrean heaven: the dwelling place of the highest group of angels, the Saints and Christ. It had also once been the habitation of the fallen angels, before they had rebelled against God and lost the war in Heaven. ${ }^{3}$ In the Aristotelian cosmological model, the demons fell through the spheres, alighting deep in the earth's core at the furthest point from God's natural location in the highest heaven (Figure 1). But as Aristotle's cosmology made a strong distinction between a perfect, unchanging celestial realm and the imperfect and corruptible region beneath the sphere of the Moon, it was easy to imagine some demons, perhaps those which were less evil, swarming in a higher airy realm from which they converged on the physical world of men to tempt and torment them. ${ }^{4}$

\footnotetext{
${ }^{1}$ On the universal potential for thinking cosmologically see Grant, Planets, Stars and Orbs,
} p. 40. I follow Grant's suggestion (p. 44) that to qualify as cosmological a text must discuss the operations of the celestial region.

${ }^{2}$ See Edward Grant, Planets, Stars, and Orbs: The Medieval Cosmos, 1200-1687

(Cambridge: Cambridge University Press, 1994), for a comprehensive discussion of the structure of the Aristotelian cosmos, which is presented in a simplified outline here.

${ }^{3}$ The most significant biblical passage is Revelation 12:7-9.

${ }^{4}$ For some scholastic debates about whether demons lived in the air or underground see J. B.

Russell, Lucifer: The Devil in the Middle Ages (Cornell, 1984), p.180. 
The emphasis on general celestial influences on the earth in Aristotle's cosmological model enabled the art of astrology to find a large degree of acceptance in intellectual circles. ${ }^{5}$ Astrology was the study of the movements and relative positions of celestial bodies in order to make predictions about human personalities, dispositions and public and personal events. It included the belief that the planets could incline men to good or evil and negatively influence the course of events. ${ }^{6}$ This had implications for medieval discussions of the origins of evil and human suffering, because it raised the question of whether and how demons could provoke, manipulate or make use of celestial influences. This chapter examines how three different kinds of medieval authors responded to this question and the different approaches to the medieval universe they subsequently proposed: theologians explaining the structure and operations of the cosmos, authors of literary and popular scientific texts exploring the origins of evil in the world, and writers of texts on astrology and magic identifying networks of power in the cosmos that could be manipulated by humans.

\section{Theologians, malign planets and fallen angels}

In the medieval understanding of the cosmos, the planets, including the sun and moon, were thought to be moved by Intelligences, a sub group of the angels, and to exert influence on the physical world in ways that were determined by the planets' nature and motion. ${ }^{7}$ The term intelligence (intelligentia) applied to an angel associated with a celestial orb was an adaptation to the Aristotelian cosmos that followed the Arabic philosopher Avicenna. To preserve the key scholastic notions of a good, omnipotent God and a perfect, incorruptible celestial region in this cosmological model, it was necessary to argue that demons could not move the planets or inhabit their spheres and that planets were natural celestial bodies that were not evil by nature or the direct cause of evil on earth. The need to clarify the relationship between planets and demons was made

\footnotetext{
${ }^{5}$ On celestial influences see Grant, Planets, Stars and Orbs, pp. 569-517 and on their relationship to astrology: J. North, 'Celestial influence - the Major Premise of Astrology' in P. Zambelli, ed., "'Astrologi hallucinati”: stars and the end of the world in Luther's time
} (Berlin: De Gruyter, 1986), pp. 45-100.

${ }^{6}$ A good overview of the dissemination of astrological texts and ideas in the Midlde Ages can be found in Hilary Carey, 'Astrology in the Middle Ages', History Compass, 8 (2010), 888902 and on medieval critics of astrology see Michael D. Bailey, Fearful Spirits, Reasoned Follies: The Boundaries of Superstition in Late Medieval Europe (Ithaca, NY: Cornell University, 2013), chapters 2 and 3.

${ }^{7}$ The question of whether Aristotle's planetary movers could be reconciled with Christian angels was resolved in favour of this position by the end of the thirteenth century. See H. A. Wolfson, "The Problem of the Souls of the Spheres," Dumbarton Oaks Papers 16 (1962): 67-92; and Grant, Planets, Stars, and Orbs, 469-87. 
more pressing by theologians' awareness of the history of pagan worship of planetary deities, and the contemporary circulation of both astrological texts that described malign planetary properties and magic texts that located morally ambiguous spirits, including demons, within the planetary spheres. ${ }^{8}$

The earliest medieval author to examine the relationship between celestial influences and manifestations of evil in the physical world in detail was William of Auvergne, Bishop of Paris from 1228 to 1249, and an important theorist of magic. William's views were based on his knowledge and condemnation of ritual magic texts that assigned spirits to different parts of the heavens and explained when and how to invoke them. In William's interpretation these spirits are identified as demons who in the past had taken the names of the planets in order to be thought to be celestial gods and in at least one case had even been permitted by God to transform into a celestial body to trick men into idolatry. ${ }^{9}$ In the present, he thought demons tried to deceive magical practitioners into believing that they had descended from heaven when in fact they had no association with the celestial realm. ${ }^{10}$ In contrast to most of his contemporaries, William denied the existence of celestial intelligences, whether good or evil. Planets were natural bodies under the direction of a good Creator and William vehemently criticised those who attributed evils (vices and sins) on earth to the planets and fixed stars. ${ }^{11}$ His criticism focused particularly on the infamous planets Mars and Saturn, noted for their malign influences in medieval cosmological and astrological texts. This kind of criticism was compatible with the defence of astrology. William's comments were cited approvingly by the French theologian, cardinal and author of astrological texts, Pierre d'Ailly. His 1410 treatise De legibus et sectis contra superstitiosos astronomos argued that it was blasphemous against God to say that the planets were evil or to attribute evils like murder, thefts, fighting and fraud to the influences of the planets. ${ }^{12}$

Most medieval thinkers accepted the idea of the natural celestial influence of the planets under the guidance of a good Creator. However, this idea raised two further questions: could demons manipulate the astral influxes descending from the heavens, and could they move the planets to influence events on earth? Several theologians, including Albertus Magnus and Thomas Aquinas, accepted that the first was possible. In his commentary on the Sentences of Peter Lombard (1246-

\footnotetext{
${ }^{8}$ On astral magic see especially, N. Weill-Parot, 'Astral Magic and Intellectual Changes
}

(Twelfth-Fifteenth (Twelfth—Fifteenth Centuries): "Astrological Images" and the Concept of “Addressative Magic,” in J. Bremner and J. Veenstra (eds.), The Metamorphosis of Magic (Leuven, 2003), 167-87.

${ }^{9}$ William of Auvergne, De universo, 2.3.8, in Opera omnia (1674, Aureliae: F. Hotot), vol. 1, p. 1033-1034.

${ }^{10}$ William of Auvergne, De universo, 2.3.6, 1:1026.

${ }^{11}$ William of Auvergne, De universo 1.1.46, chapter title: 'Contra illos, qui dicunt planetas esse malos', 1:654-7.

${ }^{12}$ Pierre d'Ailly, De legibus et sectis contra superstitiosos astronomos in De imagine mundi (Louvain, 1483), f. 43r. See also f.44v which focuses particularly on Saturn and Mars. 
49), the theologian and natural philosopher Albertus Magnus considered the first question and argued that demons could manipulate celestial influences or take on the appearances of the planets in order to do three things: perfect the magical operation of a necromancer (necromanticus), make a magician (magus vel Chaldaeus) less fearful of them, and tempt practitioners into worshipping the planetary bodies. ${ }^{13}$ Like William of Auvergne, Albertus's assessment of the relationship between demons and celestial influences was influenced by his reading of image magic texts (libri imaginum). He denied the assertion in such texts that spirits (in Albertus's interpretation, evil demons) inhabited the constellations and planets, but thought that they worked with particular constellations and signs, presumably from a sub-lunary location. Albertus also uses surprisingly positive language when explaining this relationship, for example asserting that the superior bodies help demons (superiora iuvant daemones).

The art of astrology and the category of angelic movers provided new opportunities to explain the malign activities of demons. In his Summa theologica (1265-74), Thomas Aquinas accepted the demons' use of the phases of the moon to work out when human brains were most moist and therefore susceptible to confusion (he suggests that they also do this in order to defame God's creature, ie the moon) ${ }^{14}$ But he explicitly denied that demons could move the planets in order to influence events on earth in his important treatise On Evil (De malo), probably published in 1272 towards the end of his life. ${ }^{15}$ Aquinas argued that this was not possible because of their inferior spiritual nature and their culpable damnation. ${ }^{16}$ The angelic movers did, however, provide a useful analogy for Aquinas's argument that demons had the ability to move material substances in the physical world: 'as higher spiritual substances move higher heavenly bodies, so also lower spiritual substances such as devils can cause the locomotion of lower spiritual substances. ${ }^{17}$ In the fifteenth century the same analogy was used much more ambiguously by the Spanish theologian Alonso Tostado (ca.1400-1455) to support the reality of the witches' flight to the Sabbath. Tostado argued that demons could carry witches through the air to many places by day as well as by night on the basis that they are 'equal in those natural parts to good angels' and whoever can move the heavens will also be able to move many people very quickly through the air. ${ }^{18}$ By the early fifteenth century,

${ }^{13}$ Super Sententiarum (ed. Borgnet, 1893-4), Lib.II, dist.7, art.9, p.158a.

${ }^{14}$ Summa theologica, part 1, question 114 , article 4

${ }^{15}$ Aquinas, De malo, ed. Brian Davis, trans. Richard Regan (Oxford: University Press, 2001).

Question XVI updates Aquinas' previous comments on demons to present a full and original body of doctrine centred around 12 articles.

${ }^{16}$ De malo, q. XVI, tenth article, proposition and answer 4.

${ }^{17}$ De malo, q. XVI, tenth article, answer (pp. 936-7).

${ }^{18}$ Alonso Tostado, Commentary on the Gospel of Matthew, question 47 ('An homines

portentur aliquando a diabolo per diversa loca') in Joseph Hansen, ed., Quellen und

Untersuchungen zur Geschichte des Hexenwahns und der Hexenverfolgung in Mittelalter

(Bonn: Carl Georgi, 1901), vol. 2, no. 22, p. 106. 
then, the climate of increasing belief in witchcraft had magnified the threat of demonic power: a demon with the power to move a planet no longer seemed so incredible.

\section{Idiosyncratic cosmologies in literature and popular science}

The mainstream medieval cosmological model was formulated, circulated and debated by university-trained scholars. In spite of the tensions between some of Aristotle's ideas and medieval theology, and the dominance of the scholarly quaestio that privileged specific questions and debate over synthesis, the Aristotelian cosmos was a remarkably persuasive, popular and long-lasting model. Cosmology was never an independent academic discipline, and academic syntheses of the mainstream model were rare, partly because the approaches of theologians and astronomers to the cosmos were not particularly compatible (astronomical data did not support an earth-centred cosmos). Instead, cosmological ideas and discussions flourished in diverse places, especially in works of natural philosophy, theology, astronomy and medicine. Idiosyncratic cosmologies can also be found in these genres, as well as visionary literature, heresy trials, poetic works, popular science and magic texts.

The need to make sense of the relationship between planetary influences and evil in the physical world was particularly pertinent to vernacular texts disseminating astrological ideas to general readers who were unlikely to be familiar with the theological explanations discussed above. Two creative, but nonetheless sophisticated, responses to the challenge of explaining the origins of evil and suffering are found in Chaucer's Knight's Tale (1380s) and the Middle English Wise Book of Philosophy and Astronomy (ca. 1400). In different ways both texts try to explain the relationship between planetary influences and demonic malice and activity in the context of a world overseen by an all-powerful and good Creator.

Chaucer's Knight's Tale is set in a mythological past in which the pagan deities Saturn, Venus and Mars are divine actors worshipped by humans who seek their aid in various trials. Towards the end of the narrative Saturn intervenes to resolve the apparently irreconcilable promises of Venus and Mars to help their respective human followers Palamon and Arcite, who are in love with the same woman. Arcite wins the tournament that will determine which knight will marry Emily, the idealised object of both knights' desire, but at the moment of his victory a 'furie infernal' sent by Pluto erupts out of the ground and startles Arcite's horse, causing him to fall. ${ }^{19}$ After his accident Arcite's body sinks into a Saturnine decline: it blackens, swells with clotted blood and fills with a corrupting poison that cannot be expelled. Arcite's subsequent death, caused by the combined actions of Saturn and the god of the Underworld, leaves Palamon free to marry Emily. The gods in this poem are literal deities, the channels of astrological influences and allegorical figures for time, wrath, concupiscence, but at the violent resolution of the question as to which knight will marry Emily their influence is joined to demonic causation. In keeping with this sense of combined malign forces, a strong sense of human helplessness in the face of cosmological pressures pervades the whole narrative. ${ }^{20}$

${ }^{19}$ Chaucer, Knight's Tale, part 4, 1.2684. For the association of Pluto with Christian demonic hierarchies see also Martianus Capella's suggestion that Pluto rules the air from the Moon to the Earth (De nuptiis, book 2), and Dante's location of Pluto in the seventh circle of hell

\section{(Inferno 7.1).}

${ }^{20}$ See especially Chaucer, Knight's Tale, part 3, 11. 1303-1333 for a lament against the cruelty of the gods. 
The proliferation of late medieval popular scientific texts circulating in vernacular languages from the fourteenth century were designed in part to meet this anxiety about the place of human beings in the cosmos, as well as to instruct and entertain. ${ }^{21}$ They outlined the nature and structure of the cosmos to newly literate audiences and described the effects that men and women could expect the celestial bodies to have on their lives. There is a minimum of theoretical explanations in this genre and an emphasis on dramatic personified cosmological threats. For example, a brief text devoted to the planet Saturn begins: 'Wite you nat, Saturne es ye heyest planet and Wichedeste' 22 This text goes on to outline zodiac signs in which 'he has moste powere to fulfille his malice.' But the cosmological material in scientific, utilitarian and instructional vernacular prose was also carefully Christianised, for example, by locating Christ in the empyrean heaven, emphasising the capacity of human free will to overcome planetary influences and linking biblical persons and events to astrological, chronological, cosmological divisions such as the zodiac signs, days of the week or days of the moon.

The Middle English Wise Book of Philosophy and Astronomy was a popular and relatively typical work in this genre, in circulation from ca. $1400 .{ }^{23}$ It also illustrates the kind of idiosyncratic thinking that can emerge from the popularisation of complex cosmological ideas. In the middle of the treatise, a debate by two philosophesr on predestination and free will draws the unusual and radical conclusion that the evil influences of the planets originated in the fact that they were corrupted by the original fall of the demons through the zodiac signs, and planetary and elemental spheres.

'The tenth ordre \& pe heighist of pe ten heuen, [of pe which order] Lucyffer was heighist next God, porugh his pride fill doun with many legyons \& his felawis bt hilden with hym into be deppist pitte of helle; \& euerych of hem aftir thay hadde synnyd, summe fill heigher summe fill lower, wher thorugh the signes, pe elements, \& pe planetis ben infecte $\&$ corupte. And by this cause summe ben yvell $\&$ sume ben good aftir pe influence $\&$ multitude of pe spiritis pat at pat tyme fill doun of pe tenth heuene.'

In this interpretation of the origins of planetary evil, then, the fall of the demons corrupted the cosmos, much as the fall of man infected the physical world. This absolves God of responsibility for

${ }^{21}$ My research has so far focused on the Middle English material, for which see especially G.

R. Keiser, ed., A Manual of the Writings in Middle English, 1050-1500, volume 10:

Science and Information (New Haven, 1998) and later supplements; L. Braswell,

'Utilitarian and Scientific Prose' in A.S.G. Edwards, ed., Middle English Prose: A Critical

Guide to Major Authors and Genres (New Brunswick, 1984), pp. 337-87 and L. E. Voigts,

'Scientific and Medical Books' in J. Griffiths and D. Pearsall, eds., Book Production and

Publishing in Britain 1375-1475 (Cambridge, 1989), pp. 345-402.

${ }^{22}$ London, British Library MS Sloane 213 (ca. 1400), f. 111v.

${ }^{23}$ Ed. Carrie Griffin (Heidelberg, 2013). The Wise book survives in two recensions and 34 manuscripts. 
the planets' evil influences but undermines the Aristotelian idea of a pure celestial realm and the theological idea of the planets acting as God's instruments.

\section{Cosmology and Ritual Magic}

When we turn to learned magic texts, we find diverse cosmologies that have drawn their influences from Greco-Roman, Islamic and Judaic ideas as well as Christian thinking. In this chapter I focus on one late medieval group of Christian authors in particular, whom recent historiography has called 'author-magicians.' ${ }^{24}$ Author magicians take a more scholarly approach to magic than other, (mainly earlier) Christian authors of magic texts, providing general theories and philosophical justifications and producing summae of texts and genres under their own names rather than assigning them a mythical authorship to figures like Hermes or Solomon. Although the texts of my four authors did not circulate widely, they are viewed by historians of magic as significant because the theoretical basis of their discussion of magic seems to have been acceptable to the authorities and, with one notable exception, neither they, nor their works was condemned.

In short, like the other authors of magic texts, their primary concern was to set out the powers in the universe and explain to the reader how to access them. The author-magicians are, however, all experts in astrology and their cosmologies integrate an astrological understanding of the cosmos with Christian and non-Christian ideas about spirits. Thus they provide another perspective on the question of how astrology and demonology map onto each other in Christian thinking about the Universe.

Michael Scot was a translator of Arabic treatises in the early thirteenth century, a significant disseminator of Aristotelean science in the Latin West, and an astrologer at the Court of Frederick II by the late $1220 \mathrm{~s}^{25} \mathrm{He}$ is arguably the first significant medieval author-magician, although other authors may have contributed to surviving versions of his most substantial work, the Liber introductorius (ca.1220-35). ${ }^{26}$ The Liber introductorius introduces beginner students of astrology to cosmological and theological ideas, including discussion of magical practices and the location, nature

${ }^{24}$ See Weill-Parot, “Images astrologiques” au Moyen Âge, 602-38; Boudet, Entre science et nigromance, 393-408 and Julien Véronèse, 'La notion d' 'auteur magicien' à la fin du Moyen Âge: le cas de l'ermite Pelagius de Majorque († v. 1480),' Médiévales, 51, 2006, p. 119-138.

${ }^{25}$ On Michael Scot, see especially see especially Charles Burnett, 'Michael Scot and the Transmission of Scientific Culture from Toledo to Bologna via the Court of Frederick II Hohenstaufen', Micrologus: Natura, scienze e società medievali, Le scienze alla corte di Federico II (Nature, Sciences and Medieval Societies, Sciences at the Court of Frederick II) 2 (1994) 101-126 and Lynn Thorndike, Michael Scot (London: Thomas Nelson and Sons, 1965).

${ }^{26}$ See Burnett, 'Michael Scot' for a discussion of the difficulties relating to the authorship of this text. 
and role of demons. ${ }^{27}$ It has a vague and loose structure, and surviving medieval copies differ in length, organisation and detail of content, but in general it is clear that Michael guided students of astrology towards two main attitudes to magic. On the one hand he expresses a distaste for necromancy, the deliberate conjuring of evil spirits that had been imprisoned by God in the physical realm. On the other, certain kinds of magic, such as the making of astrological talismans, are viewed positively, and he refers to angels and demons inhabiting the celestial realm who are very wise and will respond to questions. ${ }^{28}$

In his Liber introductorius Michael describes the Aristotelian model of nested spheres, unpacks the astrological dynamics of the planets' movement through the twelve zodiac signs and shows an awareness of popularising analogies that compared the cosmos to an egg or onion. As agents within and of these cosmological structures and movements, angels and demons created possibilities and dangers for the student of the science of the stars. Michael divides this science into astronomia fabulosa, astronomia superstitiosa and astronomia ymaginaria. ${ }^{29}$ The first category refers to poets' use of narratives to reveal knowledge of the heavens, the second offers a critique of astrologers who are overconfident in their predictions and the third concerns the science of things that are not visible to the senses but only to the intellect. Michael gives two examples for his final category: the lines mathematicians extend from east to west and south to north, and the evil spirits who inhabit the air around these cardinal points. The spirits in these regions belong to the order of angels and in the south are princes who rule over carnal love, and in the north, princes of hatred and other evils. ${ }^{30}$

${ }^{27}$ The Liber Introductorius is constituted of three books, the Liber quattuor distinctionem, the Liber particularis and the Liber physiognomie. On the long and short versions of the Liber introductorius see Glenn Michael Edwards, 'The Two Redactions of Michael Scot's "Liber introductorius"” Traditio, 41 (1985), pp. 329-340. The Liber particularis is edited by Oleg Voskoboynikov in Archives d'histoire doctrinale et littéraire du Moyen Âge, 81 (2014), pp. 249-384. For the first two books I have referred to the copy of the Liber introductorius in Munich, Bayerische Staatsbilbiothek, Clm 10268.

${ }^{28}$ On Michael's attitude to magic see Paolo Lucentini, 'L'ermetismo magico nel secolo XIII,' in Sic itur ad astra: Studien zur Geschichte Sic itur ad astra: Studien zur Geschichte der Mathematik und Naturwissenschaften - Festschrift für den Arabisten Paul Kunitzsch zum 70. Geburtstag, eds, Menso Folkerts, Paul Kunitzsch, Richard Lorch, (2000), pp. 420-4 and J.-P. Boudet, Entre science et nigromance: astrologie, divination et magie dans l'occident médiéval, XIIe-XVe siècle (Publications de la Sorbonne, 2006), pp. 181-6.

${ }^{29}$ Liber introductorius, prologue. Clm 10268 f. 17r.

${ }^{30}$ Liber introductorius, prologue. Clm 10268 f. 17 r. 
It seems likely that mathematical and astrological projections were thought to indicate the locations of spirits because their particular characteristics and powers lead them to inhabit parts of the cosmos with similar properties. The demons of the four cardinal points appear relatively frequently in later medieval magic rituals, theoretical treatises and works critical of magic. ${ }^{31}$ Their notoriety is indicated by their appearance in the 1398 condemnation of magic at the University of Paris which gives a detailed description of a magic ritual in which four demon kings are invoked, then cites as an error the view that there were demon 'kings' of the east, west, north and south. ${ }^{32}$ Critics of magic wanted to detach demons from associations with mathematical and astrological projections, regarding this as a distraction from their fallen status. In a further deviation from this status the Liber Introductorius locates some demons in the spheres above the moon, that is, in the perfect, incorruptible celestial realm. Michael divides the demons into nine orders and three kinds depending on the extent of their evil, although he emphasises that none are able to redeem themselves and return to the empyrean heaven. In his first reference to their location Michael states that the fallen angels can be found in all the elements under the sphere of the moon including that of water. ${ }^{33}$ Shortly afterwards he comments that the bad angels are limited to the spheres of air or fire, worse angels are present in or near the earth, and the worst of all are imprisoned in hell. ${ }^{34}$ However, in his final comment on this subject in the prologue he places the worst in hell, and the next in evil in all the elemental spheres. The least bad category of demons who are also the most wise and powerful - are now said to have remained in the ether (remansit in ethere) from the sphere of fire right up to the starry heaven. ${ }^{35}$ This places demons in the celestial realm though excluded from the empyrean heaven, whose perfection by comparison with the other

${ }^{31}$ Examples of magic texts are the Munich necromantic manual, the De tribus figuris and the De quattuor anulis. On these spirits see R. Kieckhefer, Forbidden Rites, University Park, PA: The Pennsylvania State University, 1998) p. 155-6; J-P. Boudet, "Les condemnations de la magie a Paris en 1398," Revue Mabillon 12 (2001), pp. 121-58; N. Weill-Parot, "Dans le ciel ou sous le ciel? Les anges dans la magie astrale, XIIe-XIVe siècle.” In Henri Bresc and Benoît Grévin, eds., Les anges et la magie au Moyen Âge (Rome: l'École française de Rome), pp. $760-1$.

${ }^{32}$ Article 25. See Boudet, 'Les condemnations', p. 139.

${ }^{33}$ Liber introductorius, prologue. Clm 10268 f. $4 \mathrm{v}$.

${ }^{34}$ Liber introductorius, prologue. Clm 10268 f. 4v.

${ }^{35}$ Liber introductorius, prologue, Clm 10268 f. 13v (first column): 'Et quod dicitur malum remansit in ethere ab igne supra usque ad orbem stellarum et hii sunt ceteris sapenciores in omni sciencia et potenciores ac minus mali noxa superbie'. 
celestial spheres is emphasised in Michael's commentary (ca. 1231-6), on the popular handbook of cosmology, the De Sphaera of John de Sacrobosco. ${ }^{36}$

Elsewhere in the Liber introductorius Michael is more expansive about the nature of the fallen spirits who remained in the heavens. He locates demons in the constellations, which is significant given his view that all the star groups, not just the planets, influenced the physical world. Michael asserts that the wise demons (demones sapientissimi) who inhabit groups of stars will give answers if conjured correctly. ${ }^{37}$ They can be found in the 36 decans, arcs of ten degrees in each zodiac sign, which together constituted the ecliptic (the apparent path of the sun relative to the stars). The decans had Egyptian origins and were introduced into Western Europe in Arabic magic texts, including the Picatrix. ${ }^{38}$ In the Liber particularis the location of the celestial demons (spiritus maligni) is extended to the figures of all 48 classical constellations, and Michael notes that if they are properly invoked they will be effective for experiments relevant to their particular properties. ${ }^{39}$ Although the demons' names are not given, Michael refers the reader to a Liber Adam for these. In another passage in the Liber particularis the wise spirits in their images (in faciem) are assigned to certain malicious (malignus) works like lust and hatred, however, one of the three early fourteenth century manuscripts of this text, clearly uneasy with this characterisation, replaces 'malignus' with 'magnus' (great), thus softening the moral characterisation of these spirits. ${ }^{40}$ The celestial 'images' in which demons are present are visualised as intricate magical characters in a cosmological diagram from a

${ }^{36}$ Commentary on the Sphere: lecture 4, ed. Lynn Thorndike, The Sphere of Sacrobosco and Its Commentators (Chicago: University of Chicago Press, 1949), p. 283.

${ }^{37}$ Liber introductorius, prologue, $\mathrm{Clm} 10268$ f. 16v: 'ymaginum dicit quia inter 12 signa conprobantur esse quedam ymagines numero 36 in quibus reperiuntur demones sapientissimi conmorari, et qui si rationalibiter coniurentur dant responsa et multa reducunt ad conplementum eorum que sibi firmiter inponuntur, licet non omnia.'

${ }^{38}$ On decanic spirits see D. Greenbaum, The Daimon in Hellenistic Astrology: Origins and Influence (Brill, 2015), pp. 213-22 and Benedek Láng, 'Puissances ou démons? Les images décaniques dans le Picatrix de Cracovie', in Jean-Patrice Boudet, Anna Caiozzo and Nicolas Weill-Parot, eds., Images et magie, Picatrix entre Orient et Occident (Paris: Honoré

Champion, 2011), pp. 137-148.

${ }^{39}$ Liber particularis, ch. 34, ed. Voskoboynikov, p. 299.

${ }^{40}$ Liber particularis, prologue, ed. Voskoboynikov, p. 262. 
fifteenth-century astrological anthology (Figure 2) that belonged to Wenceslas IV, King of Bohemia and contains an excerpt from the Liber introductorius. ${ }^{41}$

In Michael's Liber de signis et imaginibus celi, a description of the heavens (all the constellations and planets), one constellation in particular is singled out as the location of demons: Ara, also known as Putheus (the well) and Sacrarius (the shrine) (Figure 3). ${ }^{42}$ Illustrations of this constellation depict spirits emerging from it, clearly identifiable as demons in most manuscripts, although the text simply refers to them as very wise and cunning spirits (spiritus). Michael's commentary on the meaning of this constellation begins with its associations in ancient myth (astrologia fabulosa), then moves on to the role of its spirits in magic and divination (astrologia ymaginaria). Ara represents a place where the gods made sacrifices. According to Michael, perhaps with this ritual association in mind, the spirits inhabiting it are better than all others for conjuring, and they are called down by diviners (vates), practitioners of pyromancy (pyromantia) and necromancers (nigromantici). This commentary is typical of Michael's approach to images of the planets and constellations, which emphasised their astrological significance over their representation of classical myth. ${ }^{43}$ The fiery altar with its pagan ritual connotations made demons natural inhabitants of the constellation. At least two copyists felt uneasy enough about celestial demons to omit the depictions of spirits altogether, however, and when the physician and astrologer Louis de Langle used the Liber de signis as a model for his De figura seu imagine mundi (1456) he replaced the demons with angels. ${ }^{44}$ Michael's references to necromancy and divination were part of his intention to reveal hidden things in the cosmos, rather than a sign of approval of this art, but later authors were more explicit in linking the location of spirits to advice on effective conjuring techniques. Our next author to consider the place of demons within cosmological structures and in relation to astrological rules was Francesco Stabili, better known as Cecco d'Ascoli, whose ideas about demons can be traced in his commentary on John de Sacrobosco's De Sphaera. Like Michael Scot, Cecco's interest in demons and magic appears in the context of broader cosmological and astrological concerns. Cecco was also a professional and experienced astrologer, both in the sense of teaching astrology at the University of

${ }^{41}$ On this manuscript see David Juste, Les manuscrits astrologiques latins conservés à la Bayerische Staatsbibliothek de Munich (Paris, CNRS Editions 2011), pp 86-7, and Eric Ramírez-Weaver, 'Creative Cosmologies in Late Gothic Bohemia: Illuminated Diagrams and Memory Tools for the Court of Wenceslas IV', Manuscripta 54, 1 (2010).

${ }^{42}$ Ed. Silke Ackermann, in Sternstunden am Kaiserhof: Michael Scotus und sein Buch von den Bildern und Zeichen des Himmels (2009), p. 234.

${ }^{43}$ D. Blume, 'Michael Scot, Giotto and New Images of the Planets' in R. Duits and F. Quiviger, eds, Images of the Pagan Gods. Papers of a Conference in Memory of Jean Seznec (London: Warburg Institute, 2009), pp. 129-150.

${ }^{44}$ See Kristen Lippencott's online 'Saxl project' for a list of 16 manuscripts of the text with illustrations of Ara http://www.kristenlippincott.com/assets/Uploads/00-Ara-web-master-file13-March-2016.pdf. 
Bologna from 1322, and in his role as personal astrologer to Duke Charles of Calabria, lord of Florence (from 1326). Unlike the other authors discussed in this chapter, however, his writings brought him to the attention of the Inquisition and he was burnt at the stake in $1327 .{ }^{45}$ This has been seen by modern scholars as at least partly due to his construction of an astrological necromancy (or astrological nigromancy) that is, an unacceptable blending of the science of the stars and the conjuration of demons.

Cecco's demons are explicitly fallen spirits (Intelligences outside the grace of God), who were expelled from heaven into the air and the spheres of the other elements. ${ }^{46}$ In an approach similar to Michael Scot's astronomia ymaginaria, Cecco locates the fallen demons under significant astronomical and astrological divisions of the heavens and earth and links their activity to planetary movements. ${ }^{47}$ He places incubi and succubi under the circles of the ecliptic and suggests that the activities of these demons intensify when there is a conjunction between the three superior planets in one of the two solstical signs (Cancer and Capricorn). Demons can also be found at the North and South Poles, and four superior spirits, each with 25 legions, under the four angular signs. ${ }^{48}$ The locations of demons in Cecco's commentary suggest that their natures have drawn them to astrologically appropriate parts of the cosmos, perhaps with the implication that they are able to manipulate celestial influences flowing down in these places, an idea that is more explicit in later writers on magic. Although surviving copies of Cecco's commentary only refer to demons below the sphere of the moon, his reference to demonic Intelligences (a term normally reserved for an angelic order) and to the demon Floren originating in the Cherubim order and having a most noble nature (spiritus nobillissimus naturus) seem to have led the Inquisition to suspect him of placing demons in Heaven. The chronicler Giovanni Villani (d.1348) states that the first error mentioned in Cecco's inquisitorial condemnation of 1324 was the proposition that evil spirits were generated in the celestial spheres (spere de sopra) and that these could be constrained by invocations made under

${ }^{45}$ Commentary on the Sphere: ed. Thorndike, 343-411. See also, Nicolas Weill-Parot, 'I demoni della Sfera: La Nigromanzia cosmologico-astrologica di Cecco d'Ascoli', in: Cecco d'Ascoli: Cultura, scienza e politica nell'Italia del Trecento: Atti del convegno di studio svoltosi in occasione della XVII edizione del Premio internazionale Ascoli Piceno (2007), pp. 103-134.

${ }^{46}$ Commentary on the Sphere: ed. Thorndike, p. 39.

${ }^{47}$ For a more detailed discussion of Cecco's references to demons see: N. Weill-Parot, 'Cecco d'Ascoli and Antonio da Montolmo: The building of a "nigromantical” cosmology and the birth of the author-magician', in C. Rider and S. Page, eds, Routledge Handbook of Late Medieval Magic (forthcoming).-Parot, 'Cecco d'Ascoli and Antonio da Montolmo: The building of a "nigromantical" cosmology and the birth of the author-magician', in C. Rider and S. Page, eds, Routledge Handbook of Late Medieval Magic (forthcoming).

${ }^{48}$ Commentary on the Sphere, ed. Thorndike, ch. 2, p. 397. 
appropriate constellations to do many wonders. ${ }^{49}$ In fact, Cecco's ideas about the relationship between astrology and magic are not that different from the other authors I discuss and it is possible that other reasons, such as his outspokenness or his drawing up of a nativity of Christ, led him to be the first University scholar to be condemned.

Antonio da Montolmo's De occultis et manifestis (On Occult and Manifest Things) was influenced by Cecco's commentary on the Sphere of Sacrobosco, but in many ways his discussion of the demonic manipulation of celestial influences goes much further..$^{50}$ Like my other examples, Antonio had a background in astrology. He taught astrology and medicine at the University of Bologna from 13871392 , and was the author of an astrological text on nativities. Similarly to Cecco's commentary, but with a more serious agenda, Antonio da Montolmo's De occultis et manifestis seems to be a response to the complexity and oppressiveness of celestial influences in the Aristotelian cosmological model. ${ }^{51}$ Like the other authors discussed above, he makes sense of these influences by linking them to demonic activity. But he also seeks more explicitly to empower men and women by explaining how the Intelligences incline them to particular actions, and how they can use this knowledge for their own ends. Antonio's cosmological emphasis, like Cecco's, is primarily on vertical relationships between the heavens and Earth. The good Intelligences, who belong to the angelic order of Powers, inhabit the planetary orbs. The Intelligences deprived of divine grace inhabit the physical world, but are defined by their relationships with particular parts of the heavens.

Antonio says that he wrote his treatise De occultis et manifestis to encourage his readers to contemplate (contemplare) and speculate upon (speculare) the highest and most significant things in nature that are knowable to humans, so their souls could strive for assimilation with the Prime Mover. The highest knowable things for Antonio were the Intelligences, a category that included a sub-group of the fallen angels, who lived beneath the sphere of the moon but worked with the astral influxes (influxus or sometimes radii) of the celestial bodies. Antonio's second order of Intelligences are 'noble substances created with knowledge and nobility', fallen angels retaining many of their angelic faculties. ${ }^{52}$ They are deceitful, quarrelsome, constrained by divine power and full of malice. But, more unusually, they work with celestial influxes and thus (like the planets) have the power to incline the soul to good and evil. In Antonio's cosmology the close relationship between these

${ }^{49}$ Giovanni Villani, Nuova cronica, Book 11, ch. 41.

${ }^{50}$ On Antonio da Montolmo, and on his influence by Cecco see, Nicolas Weill-Parot [with

collab. Julien Véronèse], “Antonio da Montolmo’s De occultis et manifestis or Liber

Intelligentiarum. An Annotated Critical Edition with English Translation and Introduction,"

in Invoking Angels : Theurgic Ideas and Practices from the Thirteenth to the Sixteenth

Century, ed. Claire Fanger, University Park, PA: The Pennsylvania State University, 2012),

219-293 and N. Weill-Parot, 'Cecco d'Ascoli and Antonio da Montolmo'.

${ }^{51}$ On Antonio's knowledge of Cecco's Commentary see Weill-Parot, 'Antonio da

Montolmo's De occultis et manifestis', pp. 224-6.

${ }^{52}$ De occultis et manifestis, Prologue, 2: 'Ipse equidem Intelligentie substantie nobiles in scientia ac nobilitate create consistent.' 
Intelligences and the celestial bodies was instituted by the Devil, here called 'the very wise first Intelligence', who is knowledgeable and skilled at using the sacred influxes (sacri influxus) of the heavens. ${ }^{53}$ In order to better deceive mankind, Antonio says, the first Intelligence appointed some of his own princes to work with the celestial influences that were particularly suited to their own natural qualities.

Each prince dwells in the location where he can make best use of his constellation's astral influxes. When these influxes enter the bodies of created beings, the princes work with them to incline the soul to vice. For example, Fornifer, whose office is under the signs and stars of Venus, uses influxes from this part of the heavens to incline people to lust. In this case one could perhaps imagine a relationship between the planet and the terrestrially dwelling Intelligence that is similar to that between the fallen angel Zephyr and the Goddess Venus in the late medieval romance Perceforest. ${ }^{54}$ The characters in this romance believe in the distant influence of Venus on their lives and loves. They pray to her for protection, celebrate her feasts and give offerings at her temple. But it is the shapeshifting trickster spirit Zephyr who provides the supernatural assistance to enable lovers to come together, relationships to be consummated and the line of noble rulers of England to be perpetuated. And, just as many of Zephyr's interventions appear to have positive outcomes for good governance, so Antonio suggests that the channeling of planetary influences may be used to provoke 'honest love between two good people' as well as 'concupiscent love'. ${ }^{55}$ The application of magic to both good and evil ends is typical of Arabic astral magic, on which these later author-magicians drew, in which the goal of the operation is the fitted to the planetary natures without reference to moral consequences.

An astrological approach to the celestial realm (as Antonio puts it: celum secundum astrologos) determines the location of the Intelligences. Like Cecco d'Ascoli, Antonio situates four orders of Intelligences in the four parts of the world (East, West, South, North), where they are placed under the four cardinal signs that divided heaven according to the astrologers (Aries, Libra, Capricorn, Cancer).$^{56}$ There are also Intelligences standing beneath (constitue) each planet and an order of angels called Altitudes located under every zodiac sign, whose power varies as the celestial bodies move towards and away from aspects with each other and as the sun travels through the zodiac. ${ }^{57}$ The planetary Intelligences have the power to cause actions appropriate to their planetary influxes, such as melancholy, treachery and deceptions in the case of Saturn. Like William of Auvergne and Albertus Magnus before him, Antonio argues that the ancients worshipped these Intelligences as their gods, a practice he says is reflected in the invocations and prayers recorded in astral magic texts. Most of Antonio's treatise is concerned with who can see, invoke and constrain the Intelligences and how worthy and knowledgeable practitioners can understand and manipulate the powers of both stars and spirits. Thus the corresspondences between star and spirit set in place by

${ }^{53}$ De occultis et manifestis, ch. 5.

${ }^{54}$ Perceforest, ed. Gilles Roussineau (Droz: Geneva). Published in separate volumes between 1987 and 2014.

${ }^{55}$ De occultis et manifestis, ch. 5, section 4: 'amor honestus, qui est inter bonos, et amor concupiscentie.'

${ }^{56}$ De occultis et manifestis, ch. 1

${ }^{57}$ De occultis et manifestis, ch. 3 . 
the Devil to hide his machinations beneath the natural influxes of the heavens can also be used against him by those well trained in astrology and magic.

Giorgio Anselmi was a professor of medicine at the Universities of Parma and Bologna in 1448-49 whose imposing treatise on magic, the Opus de magia disciplina, also gave demons a significant cosmological role. ${ }^{58}$ Anselmi came to magic with a background in astrology and an interest in the making of images. Like Antonio da Montolmo he argued that magic (or superstitio, defined as the religious observance of superior things) should form part of the study of 'the wise and good philosopher' who investigated nature's secrets for the advancement of mankind and in order to become to closer to God. ${ }^{59}$ Anselmi's treatise gives a central but uncontroversial place to the influence of the motions of the celestial bodies on the inferior and corruptible world. What is radical, however, is that he gives a causal role to the four elemental spheres in his cosmology and assigns demonic movers to them. ${ }^{60}$

Anselmi's demonology incorporates ideas drawn from Platonic texts and astral magic but is grounded in mainstream Christian demonology. The influence of Apuleius's De deo Socratis and Calcidius's commentary on Plato's Timaeus is reflected in the fact that Anselmi's demons have passible natures, that is, they can suffer and some have the capacity for goodness. Like the other authors I have considered, he assigns the most power, wisdom and capacity for goodness to the demons located highest in the cosmos. In Anselmi's cosmos these are the demonic Intelligences who

${ }^{58}$ This text survives in only one sixteenth-century manuscript, Florence, Biblioteca Medicea Laurenziana, MS Plut. 44, cod. 35 (1501-10). On Giorgio Anselmi de Parme see especially Thorndike, History of Magic, 4, pp. 242-6, 677-9; Charles Burnett, 'The scapulimancy of Giorgio Anselmi's "Divinum opus de magia disciplina"” in Magic and divination in the Middle Ages (1996) p. 63-79 and N. Weill-Parot, 'Images astrologiques', pp. 622-38. I am grateful to Merlin Cox for sharing a copy of his excellent unpublished dissertation on Giorgio Anselmi: 'Similar Stars and Strange Angels: Giorgio Anselmi's Astrological Magic' (MA dissertation, Warburg Institute, 2016).

${ }^{59}$ These ideas are found throughout the text but see especially the first part of the introduction (ff.1-4).

${ }^{60}$ Divinum opus de magia disciplina, f.37v and f.40v. The following discussion draws primarily on part 2 of this text (ff. 37-52) which examines the nature, substance, variety, numbers and role of demons. 
rule the planetary bodies as subordinates to the angelic movers. ${ }^{61}$ But there are also enough evocations of Christian demonology in Anselmi's text to give it a veneer of orthodoxy. His chapter on the names of demons begins by naming the most famous: 'Satan or Satan the Transgressor, Lucifer, Temptator, Antichristus, Bahal, Bolgephor, Behel, Belzebuth, Belial, Behemoth, Lemathan. ${ }^{62} \mathrm{His}$ demons are rational, immortal beings, with exceptional knowledge and powers of movement and the ability to possess humans and decieve them with illusions and misleading dreams. Among diverse kinds of spirits, the worst are said to be evil doers, rebellious, impious and polluted (malefici et rebelles et impii et scelerati), and all demons are distinguished from the blessed angels (angeli benedicti). ${ }^{63}$

Anselmi's demons are diverse in nature and distinctions between them are often confusing, especially as he gives some sub-categories of demons the nomenclature of angels (angelus) and it is not clear whether his demonic Intelligences inhabit planetary orbs or simply manipulate their influence from the physical world. Anselmi divides demons into four types (celestial, ethereal, aerial and those that are earthly or of a moist nature) ${ }^{64}$ Sub-lunary demons may be good or evil: the airy kind love humans and elevate prayers, the moist kind are envious of humans and try to cause harm. Both can be invoked by humans in the art called the 'greater theurgy.' In Anselmi's cosmology the upper spheres are ruled by the traditional nine orders of angels, but the four elemental spheres and the four cardinal directions have their own spirits (reges et principes), who incline men to good or evil depending on their own nature. Demons also rule over the zodiac signs, planets and Caput and Cauda draconis.

The planetary demons are particularly powerful: they have the power to introduce, take away, advance and alter all things and events that fall under the nature of their planet. ${ }^{65}$ These demons seem to be sub-lunary inhabitants who work with the celestial influxes. In his only specific example of planetary demons, Anselmi notes that the demon of Saturn and his army work principally in the parts of the world, the days and hours, the people and animals, the things and events, that partake of the nature of Saturn and are moved by its motions. Of course, Saturn was a particularly appropriate example to link to the activities of demons. Anselmi also suggested that the demons of a particular planet had power over men when this planet dominated their natal horoscope or the horoscope of the solar revolution (a horoscope drawn up on successive birthdays and compared with the natal chart). ${ }^{66}$ Antonio da Montolmo had a similar proposal, that every human being was

${ }^{61}$ A 'two mover' model was considered by some scholastic authors, for example, Thomas Aquinas's commentary on the Sentences, assigns two movers to each heaven - a conjoined mover (or soul) and a separated mover (or Intelligence) (II, Sent. d. xiv, q. 1, a. 3).

${ }^{62}$ Divinum opus, f. 49v.

${ }^{63}$ Divinum opus, ff. 44r and 49v.

${ }^{64}$ Divinum opus, f. 42v: 'sunt eorum quidam celestes, alii etherei, aerii quidam, et alii humecti.'

${ }^{65}$ Divinum opus, f. 47v: 'hii qui planetis supposit sunt habent posse indando et auferendo et promovendo et alterando res omnes et accidentia quae natura sua planeta idem.'

${ }^{66}$ Divinum opus, f. 47v-48. 
allocated at birth an evil angel belonging to the order of altitudes (Intelligences standing under the twelve zodiac signs). But his view was that men born under particularly impressive planetary aspects would be able to dominate the spirits. ${ }^{67}$

Anselmi and Montolmo were writing after the failure of 'the angelic turn' in ritual magic (exemplified by magic texts like the Ars notoria, Liber flores, Almandal and Liber iuratus) to convince the authorities that the ritual invocation of angels for particular ends was an acceptable form of Christian theurgy. ${ }^{68}$ Although some angelic magic texts continued to circulate relatively widely, their frequent condemnation and, in particular, the 1323 burning of the Benedictine John of Morigny's Liber florum (a revision of the Ars notoria), undermined the idea that they would eventually be accepted as orthodox mystical technologies. In this context of condemnation, demons may have seemed a more appropriate and malleable subject than angels for magic rituals, especially when a practitioner had astrological expertise and an idiosyncratic interpretation of the cosmos. It is not clear whether it was this impulse towards the ritual exploitation of demons or the feeling of anxiety discussed earlier that led a sixteenth scribe to draw a demon's head and write demon's names around a hypothetical 'eighth sphere' in a fifteenth century cosmological diagram, pictorially locating them in heaven (Figure 4).

\section{Conclusion}

Diverse cosmological interpretations have been examined in this paper, including the ideas that demons moved, inhabited or impersonated the planets, were helped by or worked with the stars, infected them as they fell through the spheres, or simply manipulated their influences from potent locations in the physical world. We can see these attempts to bring together celestial influences and demonic activities as a rationalisation of the origins of evil and suffering that happened in spite of theologians' attempts to preserve the heavens as the creation and instrument of a good God. In the process of considering how the stars and demons combined to bring harm to humans, some authors suggested that the heavens were more corrupted than the mainstream cosmological model proposed and others made the demons less evil. Two further conclusions are possible here. We can see these approaches to the Aristotelian model as reflecting and contributing to the increasing emphasis on demonic power, malice and capacity to intervene in human life that can be tracked from the emergence of thirteenth century demonology to the fifteenth century coalescence of witchcraft mythologies. But we should also note that despite their sensitivity to cosmological pressures, magic texts on demons and the stars emphasised human agency. Higher spirits can be conjured so that they answer the practitioners' questions, astrological techniques are used to try to understand how, when and where demons inclined people to good and evil, and knowledge of the cosmos can even be used to draw humans closer to God. Like the witchcraft mythologies, this positive approach to magic also had a future in the sixteenth century and beyond.

${ }^{67}$ De occultis et manifestis, Chapter 3.

${ }^{68}$ On angelic magic see especially, Fanger, ed., Invoking Angels. 
Figures to accompany the text:

Figure 1, Fall of the Demons. London, British Library MS Egerton 2781 Neville of Hornby Hours (13251350)

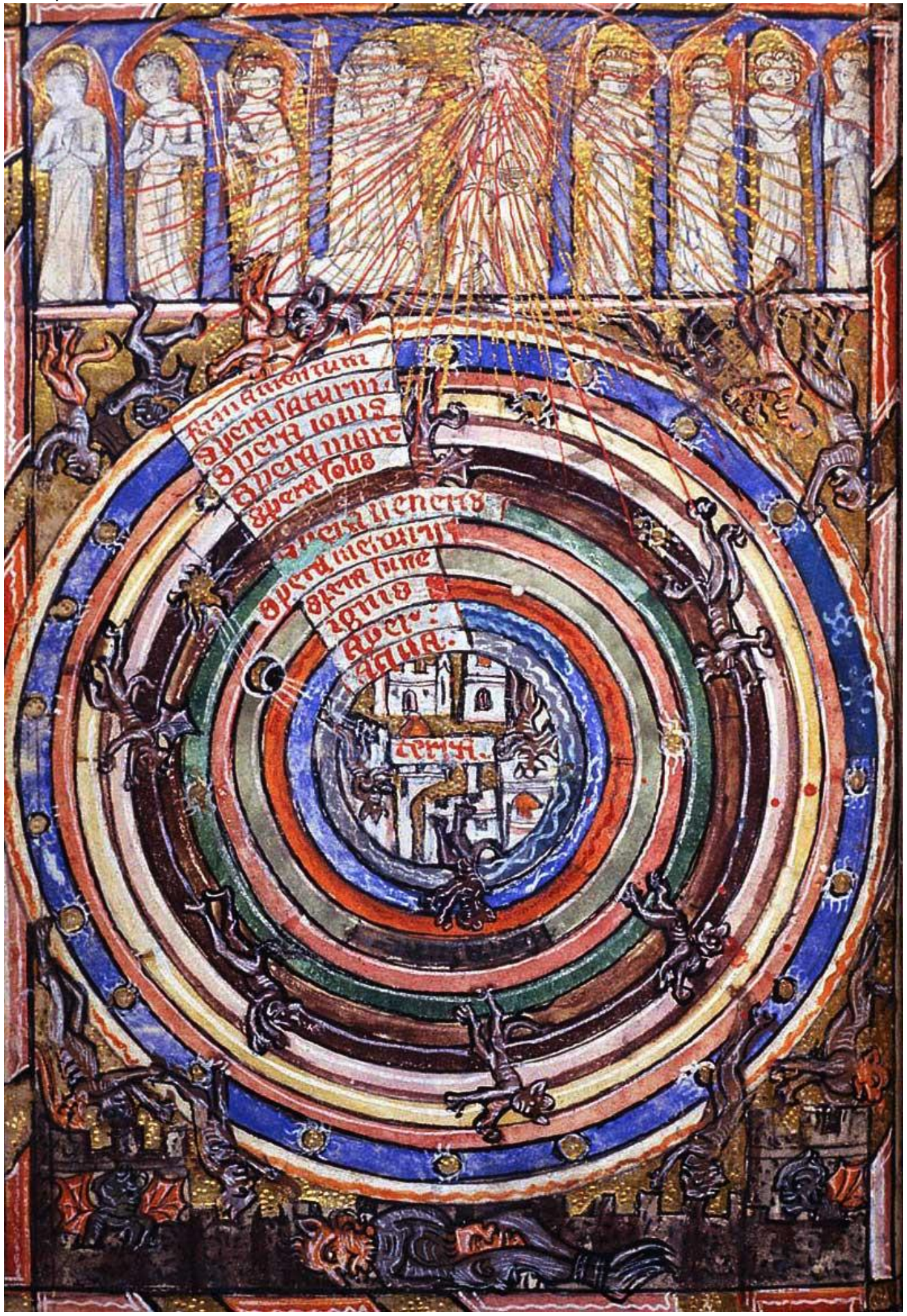


Figure 2: Cosmological diagram with magical characers. Munich, Bayerische Staatsbibliothek, MS Clm 826, f.1r.

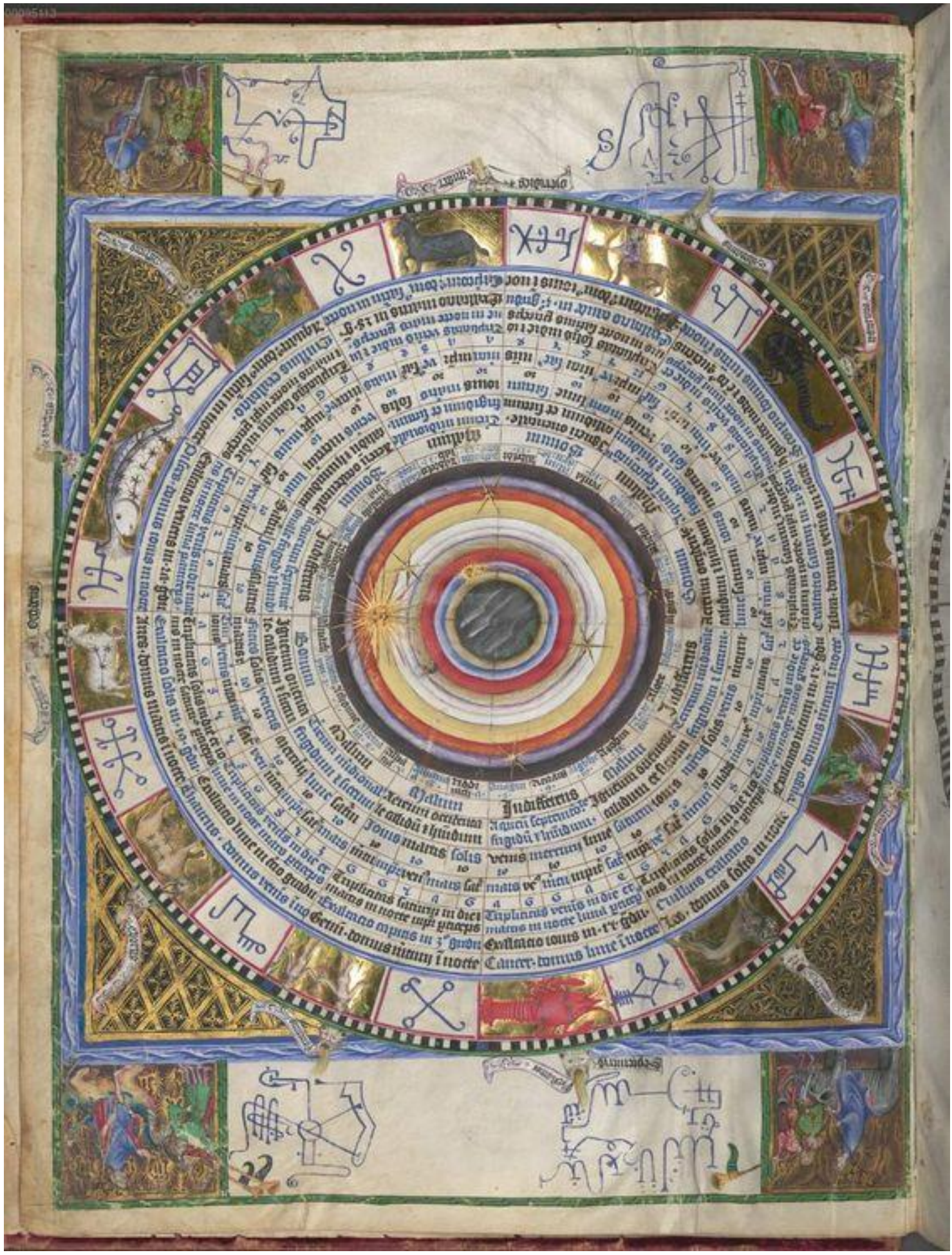


Figure 3: The Constellation Putheus from Michael Scot's Liber de signis et imaginibus celi. Munich, Bayerische Staatsbibliothek, MS Clm 10268, f. 83v

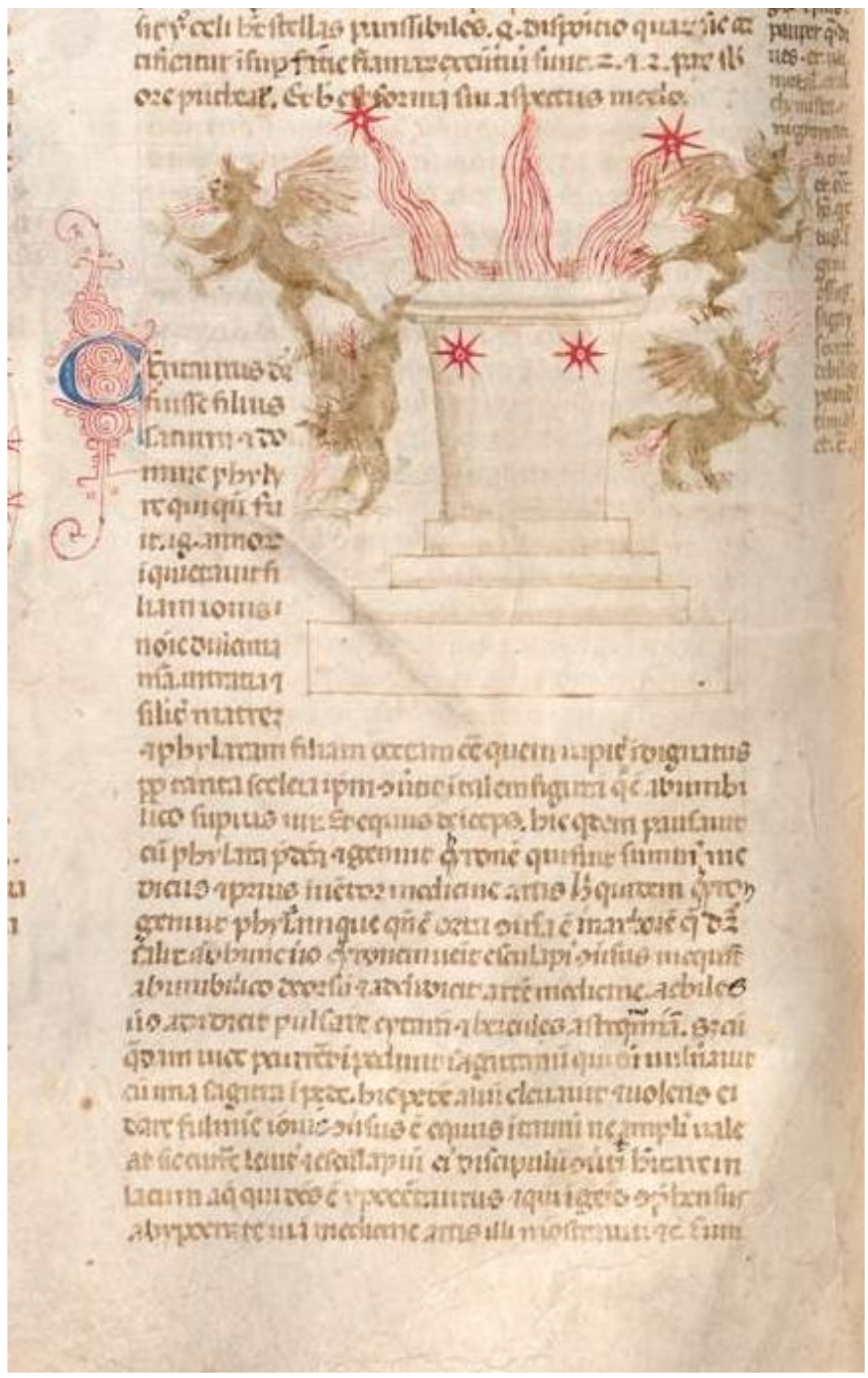


Figure 4: Cosmological diagram (fifteenth century) with a sixteenth-century drawing of a demon and demons names (Manstula . corebo . pudigopema . farantula . dalpo . perinela(?) dunali . Balba . dymeta . Fardpeon. Snaye diabole .) added around a hypothetical 'eighth sphere'. University College London, MS Lat. 12.

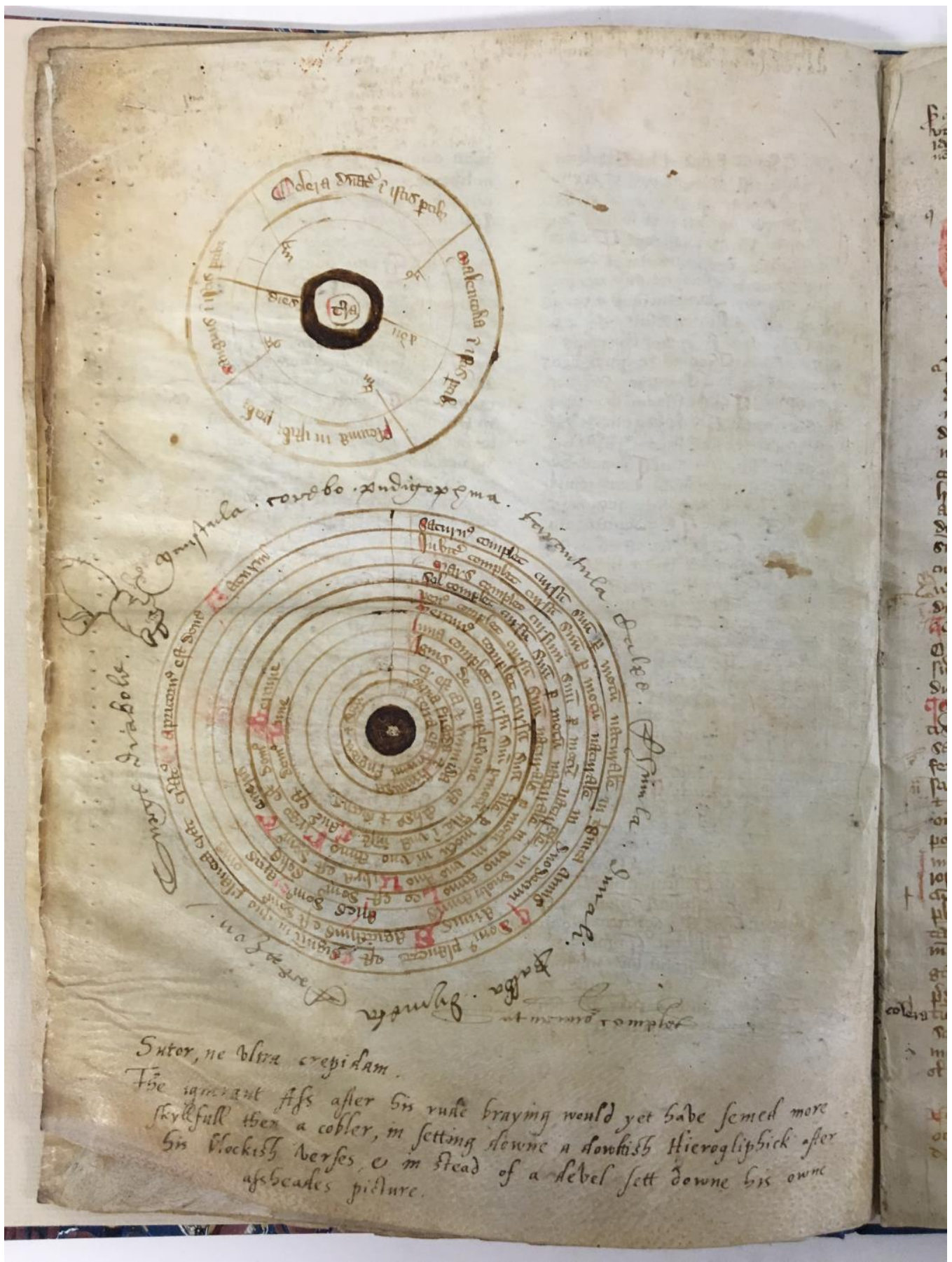

